\title{
Jaroslav Pánek, Historici mezi vědou a vědní politikou, Univerzita Pardubice, Pardubice 2016, ss. 732
}

Wybitny czeski historyk Jaroslav Pánek jest uczonym o uznanym dorobku naukowym, a jego dotychczasowe dociekania historyczne skupiały się na czeskich i środkowoeuropejskich dziejach okresu wczesnej nowożytności. Dodatkowo zajmuje się on przemianami współczesnej historiografii oraz historią kontaktów międzynarodowych i międzycywilizacyjnych. Recenzowana praca idealnie wpisuje się w drugi nurt badań J. Pánka, dlatego też w swojej nowej pracy skupia się na strukturalnych problemach historiografii po 1989 r. Książka Historici mezi vědou a vědní politikou stanowi zatem kontynuację dociekań czeskiego badacza, które zapoczątkował w książce Historici mezi domovem a světem, opublikowanej trzy lata temu w Pardubicach. Wówczas autor skupił się na historii historiografii w XIX i XX w. oraz jej wybitnych reprezentantach. W swojej nowej pracy J. Pánek zajął się zdecydowanie krótszym okresem czasowym i wybitnie szerszym kontekstem strukturalnym i międzynarodowym. Przede wszystkim autor kładzie nacisk na przemiany, jakie zaszły w latach dziewięćdziesiątych $\mathrm{XX}$ w. oraz, w jaki sposób nauki historyczne dostosowały się do nowej rzeczywistości. Rzecz jasna nie chodzi tu jedynie o warstwę metodologiczną współczesnej historiografii, ale pewne działania poza naukowe, które należało podjąć, aby lepiej dostosować politykę naukową do nowych wyzwań. Całość narracji prowadzona przez J. Pánka jest silnie sprzężona z jego doświadczeniem na stanowiskach kierowniczych w czeskich instytucjach naukowych (kierownik Wydziału Historycznego Czeskiej Akademii Nauk, zastępca prezesa Czeskiej Akademii Nauk, prorektor Uniwersytetu Karola w Pradze, prezes Czeskiego Towarzystwa Historycznego czy kierownik Czeskiego Instytutu Historycznego w Rzymie). Dlatego też recenzowana książka ma silne zaplecze empiryczne, a zatem cechuje ją rzetelność formy i skrupulatność narracji. 
Konstrukcyjnie praca J. Pánka została podzielona na pięć zasadniczych części. Pierwsza z nich („Organizační základy činnosti historiků na přelomu tisíciletí”, s. 19-327), a zarazem najdłuższa dotyczy formowania się nowych, bardziej rozbudowanych form organizacyjnych, do których czeska historiografia musiała się dostosować ze względu na zmiany środowiska naukowego i jej umiędzynarodowienia. Za jeden z głównych przykładów wszelkich zmian autor przyjął Uniwersytet Karola w Pradze, gdzie w latach 1997-2000 był prorektorem odpowiedzialnym za współpracę międzynarodową. Zaprezentował zatem liczne przykłady budowania kontaktów zagranicznych, które Uniwersytet Karola zawiązywał w Europie, Azji, Afryce czy Ameryce, a także pokazał jak wiele możliwości może stwarzać rzeczona współpraca. Rzecz jasna znalazło się tutaj również miejsce dla kontaktów Uniwersytetu Karola z polskimi placówkami historycznymi (s. 88-97), do których należą ośrodki naukowe z Opola, Częstochowy, Krakowa, Wrocławia oraz Poznania (s. 93-95). Dalej autor korzysta z przykładu Czeskiej Akademii Nauk (s. 127-169), Czeskiego Towarzystwa Historycznego (s. 171-197) oaz Czeskiego Instytutu Historycznego w Rzymie (s. 199-251), aby pokazać rozwój form pozanaukowej działalności rzeczonych instytucji. Te działania wpisują się - zatem w nową politykę naukową, która zmierza to tego, żeby instytucje historyczne znacznie rozszerzały swoją działalność na polu międzynarodowym oraz w ramach współpracy z innymi podmiotami naukowymi czy państwowymi. Oprócz instytucji naukowych, autor postanowił pokazać pewne przeobrażenia organizacyjne, towarzyszące historiografii również na przykładzie Czeskiego Czasopisma Historycznego (s. 251-270), które należało przeformułować po okresie komunizmu w znaczący periodyk naukowy.

Na koniec pierwszej części pracy J. Pánek przybliża zmiany w naukach historycznych poprzez prezentację publikacji, które mają wpływać na wzajemną rozpoznawalność czeskich historyków oraz historyków zagranicznych, zajmujących się historią Czech. J. Pánek prezentuje opublikowany leksykon współczesnych czeskich historyków (s. 271-275), a także bio-bibliograficzny leksykon zagranicznych historyków-bohemistów (s. 277-286). Również problem tworzenia encyklopedii, słowników biograficznych, popularyzacji badań historycznych (również zagranicą) oraz historii jako przedmiotu nauczania w szkołach podstawowych i średnich w Czechach, został ujęty w tej części pracy J. Pánka (s. 287-327).

Druga część recenzowanej książki („Spory o dějiny”, s. 329-411) przedstawia swego rodzaju debatę na temat charakteru badań historycznych, które na przełomie XX i XXI w. określiły dalszy kierunek rozwoju czeskiej i środkowoeuropejskiej historiografii. Rozdział ten jest pokłosiem 8 Kongresu Czeskich Historyków, który 
miał miejsce w 1999 r. w Hradcu Kralove, a na którym to podjęto debatę na temat transformacji nauk historycznych oraz reinterpretacji czeskich dziejów, również w kontekście stosunków czesko-niemieckich.

Kolejna część pracy J. Pánka („Mezinárodní souvislosti české hstoriografie”, s. 413-520) dotyczy pozycji czeskiej historiografii w świecie, która znajduje odzwierciedlenie w czeskim uczestnictwie na międzynarodowych kongresach nauk historycznych w latach 1999-2015. Autor prezentuje pozycję jaką zajmuje historia Czech (jako przedmiot badań) w zagranicznej historiografii, na przykładzie poszczególnych krajów. Oczywiście, sporo miejsca uczony poświęcił również polskiej historiografii (s. 450-452) oraz periodykowi „Historia Slavorum Occidentis” (s. 452). Dodatkowo wyabstrahował obszary badań nad dziejami Czech, które są najbardziej atrakcyjne dla zagranicznych historyków z Europy, Ameryki, Azji czy Australii.

W czwartej części („Hodnocení humanitních věd”, s. 521-596) akcenty zostały położone na aktualne tematy nauk humanistycznych. Autor pokazuje, w jaki sposób nauki humanistyczne mogą pomagać w budowaniu tożsamości regionalnej, narodowej czy europejskiej. Poza tym J. Pánek przedstawia rolę czasopism historycznych w kontekście europejskim, która sprzężona jest z nowymi wyzwaniami, które stawiane są tego typu periodykom (o zasięgu regionalnym, narodowym czy światowym). Przy okazji uczony daje liczne rady oraz sugestie, które mają pomóc w rozwoju czasopism lokalnych, aby mogły być na równi opiniotwórcze jak te globalne. Dalej autor pokazuje ewolucję nauk humanistycznych w Czeskiej Republice w latach 1990-2015 (s. 553-570) z wyróżnieniem filozofii, regionalistyki, archeologii, historii, historii sztuki, lingwistyki, literaturoznawstwa, etnologii, muzykologii oraz dodatkowo poświęca swoją uwagę historiografii i biografii historycznej (s. 571-580), a także historycznym studiom slawistycznym (s. 581-596).

Ostania część książki J. Pánka („Evropa na křižovatce”, s. 597-648) dotyczy niezwykle aktualnych problemów społeczno-politycznych, jak: masowa imigracja, problemy strukturalne Unii Europejskiej czy kryzys migracyjny, które rzecz jasna autor przedstawia w odniesieniu do historiografii. Jest to swoiste spojrzenie na transformację Europy w początkach III tysiąclecia i osobista refleksja uczonego nad tym, co w obecnej sytuacji politycznej, społecznej czy demograficznej może dać Europie sprzężenie nauk historycznych z problemami współczesnego świata. Zdanie autora w tej materii zostało wyrażone za pomocą serii otwartych wykładów, które miały miejsce na Uniwersytecie w Pardubicach, w Czeskiej Akademii Nauk, Towarzystwie Naukowym Czeskiej Republiki, Towarzystwie Nauki i Sztuki oraz na Europejskim Festiwalu Filozofii. Uczony stara się przedstawić bieżące zagadnienia społeczno- 
-polityczne w odniesieniu do warstwy metodologicznej nauk historycznych, a więc doszukuje się pewnych daleko idących trendów w rozwoju Europy.

Całość publikacji J. Pánka dopełnia streszczenie w języku angielskim (s. 651-653), podziękowania autora (s. 673-674), wykaz skrótów (s. 675-679) oraz rejestr osobowy (s. 683-706) i geograficzny (s. 707-721). Dodatkowo praca została wzbogacona o materiał ikonograficzny, na który składają się liczne fotografie, ilustrujące m.in. ożywioną działalność międzynarodową czeskich instytucji naukowych. Spis ilustracji został załączony na końcu książki (s. 655-671).

Podsumowując, można powiedzieć, iż recenzowana książka przedstawia wieloaspektowe, a zarazem kompleksowe spojrzenie na współczesną historiografię oraz inne nauki humanistyczne jako strukturę, która wymaga silnej łączności międzynarodowej. Zaznaczona w tytule polityka naukowa została ukazana w znaczeniu budowania sieci powiązań międzynarodowych oraz w aktywnym uczestnictwie historyków w infrastrukturze światowych badań humanistycznych. Z drugiej strony rzeczona polityka naukowa niesie ze sobą bardziej zaangażowany aspekt społeczny. Dzięki stworzeniu i rozwijaniu międzynarodowej platformy historycznej czy humanistycznej w ogólności, możliwe stanie się wypracowanie mechanizmów obrony przed niektórymi działaniami politycznym, które mogą źle wpłynąć na historiografię oraz naukę. Książka J. Pánka jawi się zatem jako poważny głos w dyskusji nad dalszym rozwojem nauk historycznych na obszarze środkowoeuropejskim. Praca czeskiego historyka jest zatem publikacją godną polecenia, ponieważ dotyka niezwykle istotnych aspektów badań historycznych, a zarazem przedstawia rozwój historiografii w ostatnim ćwierćwieczu z czeskiej perspektywy. Wypada więc życzyć sobie, aby podobna publikacja ukazała się na gruncie polskiej historiografii.

mgr ROBERT T. TOMCZAK

Instytut Historii

Wydział Historyczny

Uniwersytet im. Adama Mickiewicza

ul. Umultowska 89d

61-614 Poznań

robertomczak@yahoo.com 